\title{
Analisis Pengaruh System Quality, Information Quality, Service Quality Terhadap Net Benefit Pada Sistem KRS-Online Universitas Muhammadiyah Malang
}

\author{
M. Asrar Fathoni ${ }^{*}$, Gita Indah' ${ }^{2}$, Wildan Suharso ${ }^{3}$ \\ 1, 2, 3 Universitas Muhammadiyah Malang \\ asrarawr@gmail.com*
}

\begin{abstract}
Abstrak
Implementasi sistem informasi KRS-online dalam perkuliahan digunakan untuk membantu proses penyusunan KRS oleh setiap mahasiswa Universitas Muhammadiyah Malang. Penelitian ini bertujuan untuk mengukur dan menguji variabel-variabel serta indikator yang mempengaruhi kesuksesan sistem informasi KRS-online UMM. Model penelitian ini mengadopsi model penelitian DeLone and Mclean IS Success. Kuesioner yang disusun dalam penelitian ini disebarkan kepada 100 responden yang memiliki kualifikasi sebagai mahasiswa pengguna sistem KRS-online. Uji validitas dan uji reliabilitas dilakukan untuk memperoleh data yang valid dan reliabel. Hasil penelitian menunjukkan bahwa kualitas sistem memiliki pengaruh yang signifikan terhadap kepuasan pengguna, kualitas informasi memiliki pengaruh yang signifikan terhadap kepuasan pengguna, kualitas layanan memiliki pengaruh yang signifikan terhadap kepuasan pengguna dan kepuasan pengguna memiliki pengaruh yang signifikan terhadap net benefit. Berdasarkan hasil Analisis ditunjukkan bahwa kesuksesan sistem informasi KRS-online UMM memiliki persentase sebesar 70,5\% yang artinya kesuksesan sistem informasi KRS-online UMM berada pada tingkatan sukses.
\end{abstract}

Kata kunci: Model Delone and Mclean, KRS-Online, Kepuasan Pengguna, Net Benefit, Kesuksesan.

\begin{abstract}
Implementation of online-KRS of information system in the lecture is used to assist the preparation of KRS by every student of the Universitas Muhammadiyah Malang. This study aims to measure and examine the variables and indicators that affect the success of information system of online-KRS in UMM. The research model was adopted from DeLone and Mclean IS Success. A set of questionnaire are compiled in this study and distributed to 100 respondents who qualified as KRS-online system users. The validity and reliability tests is conducted to obtain data that is valid and reliable. These results indicate that the quality system has significant influence toward the user satisfaction, the quality of information has a significant influence on user satisfaction, service quality has a significant influence on user satisfaction and user satisfaction have a significant effect on the net benefit. Based on the analysis, the success of information system of online-KRS of UMM has $70.5 \%$ success which can be categorized as succeeded.
\end{abstract}

Keywords: Delone and Mclean, KRS-Online, User Satisfication, Net Benefit, Success.

\section{Pendahuluan}

Teknologi komputer dan internet bukan lagi menjadi hal yang asing di masyarakat. Komputer dapat digunakan sebagai salah satu alat yang efektif dan mudah, sedangkan internet sendiri sebagai sumber pengetahuan dan ilmu yang hampir tidak terbatas. Dengan adanya komputer dan internet beberapa pekerjaan menjadi lebih mudah dan dapat terselesaikan dengan cepat. Kita bisa mendapatkan informasi terbaru dan akurat, serta pengelolaan dan pengolahan data dalam jumlah yang banyak menjadi lebih mudah dan cepat [1]. Menurut penelitian yang dilakukan oleh Radityo dan Zulaikha pada tahun 2007 [2] dipaparkan bahwa sistem informasi yang didukung TI dapat memberikan nilai tambah bagi organisasi jika didesain menjadi sistem informasi yang efektif, namun demikian, pengukuran kesuksesan atau penilaian kualitas suatu 
sistem informasi yang efektif sulit dilakukan secara langsung. Kesulitan penilaian kesuksesan dan keefektifan sistem informasi secara langsung mendorong banyak peneliti mengembangkan model untuk menilai kesuksesan sistem informasi [2].

Pada tahun 2003, Mclean dan Delone kembali mengembangkan teorinya tentang kesuksesan sistem informasi dengan menambahkan kualitas layanan (service quality) dan menggabungkan dampak individu dan dampak organisasi menjadi manfaat-manfaat bersih (net benefit) [3]. Teori Delone dan Mclean sudah diterapkan oleh beberapa peneliti seperti yang dilakukan Saputro pada tahun 2016 yang mengukur kesuksesan sistem informasi e-government pada Pemerintahan [4]. Penelitian yang dilakukan oleh Utami pada tahun 2013 mencari item-item yang mempengaruhi sistem informasi dan mengukur kesuksesan sistem informasi akademik [5], dan yang dilakukan oleh Falgenti pada tahun 2013 yang melakukan evaluasi sistem informasi ERP pada usaha kecil dan menengah [6].

Beberapa sistem informasi yang terdapat pada Universitas Muhammadiyah Malang yakni Sistem Kartu Rencana Studi Mahasiswa secara online atau yang biasa disebut dengan KRSonline, Sistem KHS-online, Sistem e-learning pada jurusan Teknik Informatika, dan masih banyak lagi. Penelitian ini dilakukan dengan tujuan mengukur kesuksesan sistem informasi di perguruan tinggi pada studi kasus KRS-online Universitas Muhammadiyah Malang (UMM), dimana belum ada penerapan yang dilakukan untuk mengukur kesuksesan pada sistem informasi UMM dengan pendekatan DeLone and Mclean. Pengukuran ini merujuk pada penelitian yang dilakukan Livari yang dilakukan pada tahun 2005 yang hanya menggunakan variabel kepuasan pengguna (user satisfication) sebagai variabel mediasi yang menghubungkan antara quality dengan net-benefit [7]. Sedangkan variabel penggunaan (use) yang juga merupakan variabel mediasi pada model kesuksesan Delone and Mclean dijadikan sebagai batasan.

Penelitian ini berusaha mengetahui sejauh mana tingkat kesuksesan KRS-online dengan meneliti hubungan antar variabel dengan pendekatan Model Kesuksesan Sistem Informasi DeLone dan McLean (2003). Dimana akan memfokuskan apakah terdapat pengaruh antara sistem yang digunakan terhadap kepuasan pengguna, pengaruh informasi yang ada pada sistem terhadap kepuasan pengguna, pengaruh layanan yang diberikan oleh sistem terhadap kepuasan pengguna, pengaruh kepuasan pengguna terhadap manfaat-manfaat bersih pada sistem KRSonline UMM dan dari variabel-variabel yang diteliti akan menggambarkan tingkat kesuksesan sistem KRS-online.

\section{Metode Penelitian}

Metodologi yang digunakan untuk mengukur kesuksesan penerapan pada sistem KRSonline UMM meliputi beberapa hal antara lain menentukan model pengukuran kesuksesan sistem informasi, menyusun hipotesis, menentukan populasi dan sampel, analisis hasil dan pengujian.

\subsection{Pengukuran Kesuksesan Sistem Informasi}

Konsep kesuksesan sistem informasi merupakan suatu konsep yang digunakan dalam berbagai riset sebagai kriteria dasar untuk mengevaluasi sistem informasi. Penelitian ini menggunakan variabel dari Model DeLone and Mclean (2003) untuk mengetahui suatu efektivitas sistem informasi yang akan diteliti, sedangkan model yang akan digunakan merupakan model yang merujuk pada penelitian Livari (2005) yang meliputi kualitas sistem (system quality), kualitas informasi (information quality), kualitas layanan (service quality), kepuasan pengguna (user satisfication) dan manfaat-manfaat bersih (net benefit).

Pada Gambar 1 ditunjukkan model konseptual yang digunakan pada penelitian yang meliputi kualitas sistem, kualitas informasi, kualitas layanan, kepuasan pengguna, dan net benefit. Berdasarkan model konseptual tersebut disusun hipotesis-hipotesis yang digunakan dalam penelitian.

\subsection{Hipotesis}

Hipotesis-hipotesis yang disusun berdasarkan model konseptual adalah sebagai berikut:

1. Kualitas sistem terhadap kepuasan pengguna.

$\mathrm{H}_{0(1)}$ : Tidak terdapat pengaruh yang signifikan antara variabel kualitas sistem (system quality) dengan kepuasan pengguna (user satisfication). 
$\mathrm{H}_{a(1)}$ : Terdapat pengaruh yang signifikan antara variabel kualitas sistem (system quality) dengan kepuasan pengguna (user satisfication).

2. Kualitas Informasi terhadap kepuasan pengguna.

$\mathrm{H}_{0(2)}$ : Tidak terdapat pengaruh yang signifikan antara variabel kualitas informasi (information quality) dengan kepuasan pengguna (user satisfication).

$\mathrm{H}_{a(2)}$ : Terdapat pengaruh yang signifikan antara variabel kualitas informasi (information quality) dengan kepuasan pengguna (user satisfication).

3. Kualitas layanan terhadap kepuasan pengguna.

$\mathrm{H}_{0(3)}$ : Tidak terdapat pengaruh yang signifikan antara variabel kualitas layanan (service quality) dengan kepuasan pengguna (user satisfication).

$\mathrm{H}_{a(3)}$ : Terdapat pengaruh yang signifikan antara variabel kualitas layanan (service quality) dengan kepuasan pengguna (user satisfication).

4. Kepuasan pengguna terhadap manfaat-manfaat bersih.

$\mathrm{H}_{0(4)}$ : Tidak terdapat pengaruh yang signifikan antara variabel kepuasan pengguna (user satisfication) dengan manfaat-manfaat bersih (net benefit).

$\mathrm{H}_{a(4)}$ : Terdapat pengaruh yang signifikan antara variabel kepuasan pengguna (user satisfication) dengan manfaat-manfaat bersih (net benefit).

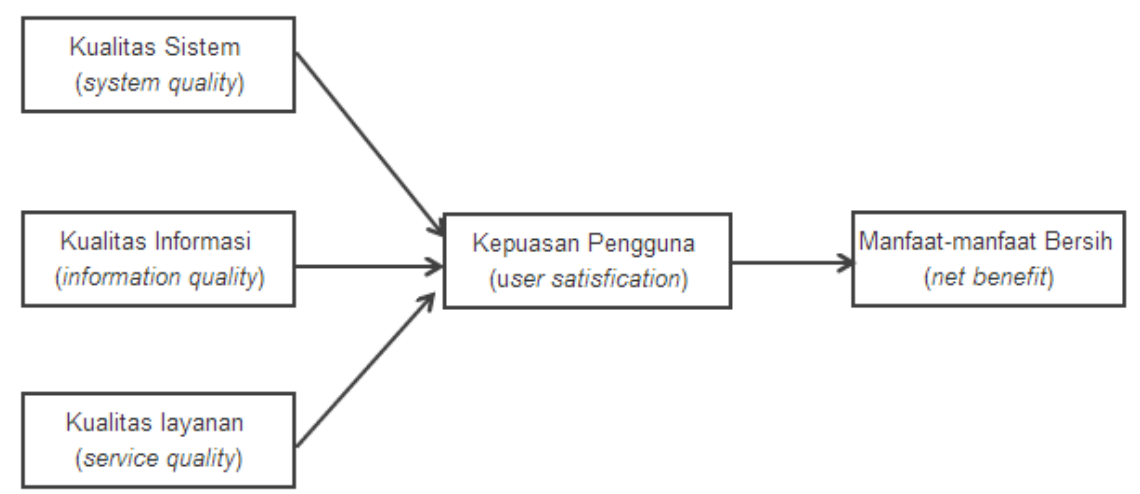

Gambar 1. Model Konseptual

\subsection{Populasi dan Sampel}

Diketahui user dari pengguna sistem informasi KRS-online UMM sebanyak 26000 mahasiswa dari sumber website. Dilihat dari batasan masalah, sampel yang digunakan adalah mahasiswa angkatan 2012 dan 2013 Universitas Muhammadiyah Malang yaitu sebanyak 13000 mahasiswa yang dikarenakan setengah dari total keseluruhan mahasiswa adalah 26.000. Teknik pengukuran ukuran sampel ini menggunakan rumus Slovin dengan taraf kesalahan error sebesar 10\% yang ditunjukkan pada Persamaan 1.

$$
n=\frac{N}{1+N(e)^{2}}
$$

Keterangan:

$\mathrm{n}=$ Ukuran sampel

$\mathrm{N}=$ Ukuran populasi

e $=$ Taraf kesalahan error sebesar $0.10(10 \%)$

Dari rumus di atas, maka besar sampel (n) serta populasi (N) sebanyak 13000 mahasiswa dengan hasil perhitungan Persamaan 1.

$$
n=\frac{13000}{1+13000(0.10)^{2}}=99,23
$$

Berdasarkan hasil perhitungan Persamaan 1 maka diketahui nilai $\mathrm{n}$ sebesar 99,23 sehingga dibulatkan menjadi 100, maka jumlah sampel yang akan digunakan dalam penelitian ini adalah sebanyak 100 orang.

Analisis Pengaruh System Quality, Information Quality, Service Quality..., M. Asrar Fathoni, Gita Indah, Wildan Suharso 


\subsection{Instrumen Penelitian}

Instrumen penelitian yang digunakan dalam penelitian ini adalah dalam bentuk kuesioner atau angket, karena kuesioner dapat memberikan kemudahan bagi responden untuk memahami dan menjawab pertanyaan yang diajukan dengan baik disebabkan responden memiliki waktu yang cukup lama untuk berpikir dan menyelesaikan kuesioner tersebut. Pengukuran kuesioner dalam penelitian ini menggunakan skala likert yang digunakan untuk mengukur sikap, pendapat dan persepsi seseorang atau sekelompok orang tentang fenomena social [8]. Bentuk standar skala likert adalah 1 sampai 5 , tapi pada penelitian ini menggunakan skala 1 sampai 4 untuk menghilangkan jawaban bersifat netral atau ragu-ragu.

Tabel 1. Parameter Skala Likert

\begin{tabular}{cc}
\hline Skor & Kriteria Jawaban \\
\hline 1 & Sangat Tidak Setuju (STS) \\
\hline 2 & Tidak Setuju (TS) \\
\hline 3 & Setuju (TS) \\
\hline 4 & Sangat Setuju (SS) \\
\hline
\end{tabular}

Pada Tabel 1 ditunjukkan kriteria jawaban berdasarkan skor yang ditunjukkan dengan angka, skor 1 menunjukkan bahwa kriteria sangat tidak setuju dan skor tertinggi, yaitu skor 4 menunjukkan kriteria jawaban sangat setuju.

\section{Hasil Penelitian dan Pembahasan 3.1 Uji Kelayakan Kuesioner \\ 3.1.1 Uji Validitas}

Uji validitas digunakan untuk mengukur sah atau valid tidaknya suatu kuesioner. Uji validitas pada penelitian ini menggunakan $30 \%$ dari total responden yang ditargetkan, yaitu 30 mahasiswa dari total 100 mahasiswa. Tabel 2 adalah bagaimana untuk menentukan nilai $\mathrm{R}_{\text {Tabel }}$ pada tabel $r$.

Tabel 2. Penentuan $R$ Tabel

\begin{tabular}{cccc}
\hline Jumlah Responden $(\mathrm{n})$ & $\mathrm{df}(\mathrm{n}-2)$ & Peluang kesalahan $(\alpha)$ & RTabel \\
\hline 30 & 28 & 0,10 & 0,3061 \\
\hline
\end{tabular}

Berdasarkan data diatas, nilai df adalah 28 dan $(\alpha)=0,10$, maka nilai $R_{\text {Tabel }}$ untuk membandingkan nilai RHitung adalah 0,3061 (Lampiran pada tabel distribusi r). Tabel 3 menunjukkan hasil uji validitas dimana $r$ hitung akan dibandingkan dengan $r$ tabel.

Berdasarkan hasil output SPSS menunjukkan bahwa item pertanyaan KS2, KS3, KS6, $\mathrm{KS} 10, \mathrm{KI} 8, \mathrm{KL} 1, \mathrm{KL} 7$ dan NB8 yang memiliki nilai $\mathrm{R}_{\text {Hitung }}<\mathrm{R}_{\text {Tabel }}$ pada instrumen penelitian dapat

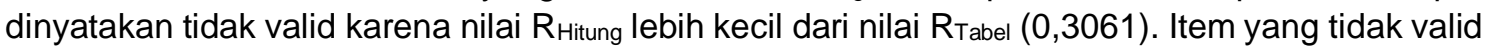
akan dibuang karena tidak memiliki nilai validitas sebagai pengukuran validitas. Sedangkan item pertanyaan yang memiliki nilai $R_{\text {Hitung }}>R_{\text {Tabel }}$ pada instrumen penelitian dapat dinyatakan valid

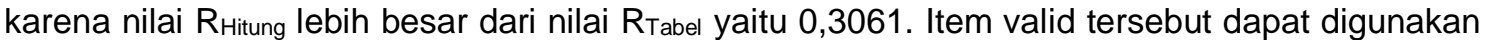
sebagai item pengukuran dimana total keseluruhan itemnya setelah dilakukan validitas sebanyak 29 pertanyaan.

\subsubsection{Uji Reliabilitas}

Reliabilitas adalah alat untuk mengukur suatu kuesioner yang merupakan indikator dari variabel. Suatu kuesioner dikatakan reliabel jika jawaban seseorang terhadap pernyataan adalah konsisten atau stabil dari waktu ke waktu. Tabel 4 menunjukkan hasil uji reliabilitas.

Hasil pengujian reliabilitas pada Tabel 4 menunjukkan hasil Cronbach's Alpha memiliki nilai 0,870 dan dibandingkan dengan pedoman reabilitas yang berarti semua data yang diuji untuk variabel kesuksesan memiliki nilai reliabilitas sangat tinggi karena termasuk diantara nilai 0.800 $-1,000$ [9]. 
Tabel 3. Hasil Uji Validitas

\begin{tabular}{|c|c|c|c|}
\hline Item Indikator & R Hitung & R Tabel & Keterangan \\
\hline KS1 & 0,372 & 0,3061 & Ket \\
\hline KS2 & 0,220 & 0,3061 & Valid \\
\hline KS3 & 0,022 & 0,3061 & Tidak Valid \\
\hline KS4 & 0,729 & 0,3061 & Tidak Valid \\
\hline KS5 & 0,434 & 0,3061 & Valid \\
\hline KS6 & 0,079 & 0,3061 & Valid \\
\hline KS7 & 0,484 & 0,3061 & Tidak Valid \\
\hline KS8 & 0,754 & 0,3061 & Valid \\
\hline KS9 & 0,356 & 0,3061 & Valid \\
\hline KS10 & 0,202 & 0,3061 & Valid \\
\hline $\mathrm{KI} 1$ & 0,410 & 0,3061 & Tidak Valid \\
\hline $\mathrm{K} 12$ & 0,324 & 0,3061 & Valid \\
\hline $\mathrm{KI} 3$ & 0,619 & 0,3061 & Valid \\
\hline $\mathrm{KI} 4$ & 0,418 & 0,3061 & Valid \\
\hline KI5 & 0,608 & 0,3061 & Valid \\
\hline KI6 & 0.407 & 0,3061 & Valid \\
\hline $\mathrm{KI} 7$ & 0,531 & 0,3061 & Valid \\
\hline $\mathrm{KI} 8$ & 0,226 & 0,3061 & Valid \\
\hline KL1 & 0,218 & 0,3061 & Tidak Valid \\
\hline KL2 & 0,726 & 0,3061 & Tidak Valid \\
\hline KL3 & 0,546 & 0,3061 & Valid \\
\hline KL4 & 0,551 & 0,3061 & Valid \\
\hline KL5 & 0,367 & 0,3061 & Valid \\
\hline KL6 & 0,338 & 0,3061 & Valid \\
\hline KL7 & 0,245 & 0,3061 & Valid \\
\hline KL8 & 0,483 & 0,3061 & Tidak Valid \\
\hline KP1 & 0,415 & 0,3061 & Valid \\
\hline KP2 & 0,562 & 0,3061 & Valid \\
\hline NB1 & 0,661 & 0,3061 & Valid \\
\hline NB2 & 0,375 & 0,3061 & Valid \\
\hline NB3 & 0,356 & 0,3061 & Valid \\
\hline NB4 & 0,597 & 0,3061 & Valid \\
\hline NB5 & 0,669 & 0,3061 & Valid \\
\hline NB6 & 0,588 & 0,3061 & Valid \\
\hline NB7 & 0,523 & 0,3061 & Valid \\
\hline NB8 & 0,029 & 0,3061 & Valid \\
\hline NB9 & 0,387 & 0,3061 & Tidak Valid \\
\hline
\end{tabular}

Tabel 4. Uji Reliabilitas

\begin{tabular}{cc}
\hline Cronbach's Alpha & N of items \\
\hline 0,870 & 37 \\
\hline
\end{tabular}

\subsubsection{Uji T}

Uji ini digunakan untuk menentukan seberapa besar pengaruh suatu variabel bebas terhadap variabel terikat secara parsial dengan taraf kesalahan $\alpha=10 \%$ dan akan menghasilkan nilai untuk mengukur nilai hipotesis. Hasil output dari SPSS terhadap data skor yang telah dibuat berdasarkan jawaban 100 responden dari kuesioner yang telah dibagikan. Bila nilai signifikan tersebut lebih kecil dari tingkat Alpha $(\alpha)=0,1$ maka dinyatakan bahwa variabel bebas tersebut memiliki pengaruh yang signifikan terhadap variabel terikat.

Berdasarkan taraf 0.05 dan $\mathrm{df}=96$, maka nilai TTabel untuk membandingkan nilai $T_{\text {Hitung }}$ adalah sebesar 1,664. Sedangkan nilai TTabel untuk variabel terikat net benefit (NB) dengan taraf 0.05 dan $\mathrm{df}=98$, maka nilai $\mathrm{T}_{\text {Tabel }}$ untuk membandingkan nilai $\mathrm{T}_{\text {Hitung }}$ adalah sebesar 1,66. Nilai TTabel kemudian dirangkum menjadi bahasan-bahasan sebagaimana yang terlihat pada Tabel 5. 
Berdasarkan Tabel 5 dapat diketahui nilai $T_{\text {Hitung }}$ dari kualitas sistem terhadap kepuasan pengguna adalah 2,742 dan nilai signifikannya adalah 0,008, sedangkan bila dibandingkan dengan nilai $T_{\text {Tabel }}$ yang terdapat pada Tabel untuk taraf signifikansi 0,1 dan dengan jumlah $n$ adalah 100, nilai $T_{\text {Tabel yang didapat adalah 1,664. Dalam hal ini } T_{\text {Hitung }}>T_{\text {Tabel }}(2,742>1,664) \text { dan }}$ besarnya nilai signifikan yang lebih kecil dari taraf signifikan $(0,007<0,1)$, sehingga $\mathrm{H}_{a(1)}$ diterima dan $\mathrm{H}_{0(1)}$ ditolak.

\begin{tabular}{|c|c|c|c|}
\hline Variabel & $T_{\text {Hitung }}$ & TTabel & Sig. \\
\hline Kualitas Sistem Terhadap Kepuasan Pengguna & 2,742 & 1,664 & 0,007 \\
\hline Kualitas Informasi Terhadap Kepuasan Pengguna & 1,760 & 1,664 & 0,082 \\
\hline Kualitas Layanan Terhadap Kepuasan Pengguna & 2,264 & 1,664 & 0,026 \\
\hline Kepuasan Pengguna Terhadap Net Benefit & 5,939 & 1,664 & 0,000 \\
\hline
\end{tabular}

Pengujian pada kualitas informasi terhadap kepuasan pengguna memperoleh hasil THitung sebesar 1,760 dan nilai signifikannya adalah 0,082, sedangkan bila dibandingkan dengan nilai TTabel yang terdapat pada TTabel untuk taraf signifikansi 0,1 dan dengan jumlah $\mathrm{n}$ adalah 100, nilai TTabel yang didapat adalah 1,664. Dalam hal ini $T_{\text {Hitung }}>\mathrm{T}_{\text {Tabel }}(1,760>1,664)$ dan besarnya nilai signifikan yang lebih kecil dari taraf signifikan $(0,082<0,1)$, sehingga $\mathrm{H}_{a(2)}$ diterima dan $\mathrm{H}_{0(2)}$ ditolak.

Pengujian pada kualitas layanan terhadap kepuasan pengguna memperoleh hasil THitung sebesar 2,264 dan nilai signifikannya adalah 0,026, sedangkan bila dibandingkan dengan nilai TTabel yang terdapat pada t tabel untuk taraf signifikansi $10 \%$ dan dengan jumlah $\mathrm{n}$ adalah 100 , nilai TTabel yang didapat adalah 1,664. Dalam hal ini $\mathrm{T}_{\text {Hitung }}>\mathrm{T}_{\text {Tabel }}(2,264>1,664)$ dan besarnya nilai signifikan yang lebih kecil dari taraf signifikan $(0,026<0,1)$, sehingga $\mathrm{H}_{a(3)}$ diterima dan $\mathrm{H}_{0(3)}$ ditolak.

Berdasarkan tabel 5 dapat diketahui nilai t hitung dari kepuasan pengguna terhadap net benefit adalah 5,939 dan nilai signifikannya adalah 0,000, sedangkan bila dibandingkan dengan nilai $\mathrm{T}_{\text {Tabel }}$ yang terdapat pada t tabel untuk taraf signifikansi $10 \%$ dan dengan jumlah $\mathrm{n}$ adalah 100, nilai T Tabel yang didapat adalah 1,664. Dalam hal ini $T_{\text {Hitung }}>T_{\text {Tabel }}(2,714>1,664)$ dan besarnya nilai signifikan yang lebih kecil dari taraf signifikan $(0,000<0,1)$, sehingga $\mathrm{H}_{a(4)}$ diterima dan $\mathrm{H}_{0(4)}$ ditolak.

\subsection{Uji Hipotesis}

\subsubsection{Kualitas Sistem Terhadap Kepuasan Pengguna}

Berdasarkan hasil pada pengujian uji t, dapat disimpulkan bahwa kualitas sistem memiliki pengaruh yang signifikan terhadap kepuasan pengguna. Hal ini dibuktikan dengan lebih besarnya nilai signifikan yang lebih kecil dari taraf signifikan $(0,007<0,1)$ sehingga terdapat pengaruh yang signifikan dan besarnya thitung dibandingkan dengan pada t tabel $(2,742>1,664)$, sehingga $\mathrm{H}_{a(1)}$ diterima.

$\mathrm{H}_{\mathrm{a}(1)}$ : Terdapat pengaruh yang signifikan antara variabel kualitas sistem (system quality) dengan kepuasan pengguna (user satisfication).

\subsubsection{Kualitas Informasi Terhadap Kepuasan Pengguna}

Berdasarkan hasil pada pengujian uji t, dapat disimpulkan bahwa kualitas informasi memiliki pengaruh yang signifikan terhadap kepuasan pengguna. Hal ini dibuktikan dengan lebih besarnya nilai signifikan yang lebih kecil dari taraf signifikan $(0,082<0,1)$ sehingga terdapat pengaruh yang signifikan dan besarnya t hitung dibandingkan dengan pada t tabel $(1,760>$ 1,664), sehingga $\mathrm{H}_{a(2)}$ diterima.

$\mathrm{H}_{\mathrm{a}(2)}$ : Terdapat pengaruh yang signifikan antara variabel kualitas informasi (information quality) dengan kepuasan pengguna (user satisfication).

\subsubsection{Kualitas Layanan Terhadap Kepuasan Pengguna}

Berdasarkan hasil pada pengujian uji t, dapat disimpulkan bahwa kualitas layanan memiliki pengaruh yang signifikan terhadap kepuasan pengguna. Hal ini dibuktikan dengan lebih besarnya nilai signifikan yang lebih kecil dari taraf signifikan $(0,026<0,1)$ sehingga terdapat 
pengaruh yang signifikan dan besarnya $t$ hitung dibandingkan dengan pada $t$ tabel $(2,264>$ 1,664), sehingga $\mathrm{H}_{a(3)}$ diterima.

$\mathrm{H}_{\mathrm{a}(3)}$ : Terdapat pengaruh yang signifikan antara variabel kualitas layanan (service quality) dengan kepuasan pengguna (user satisfication).

\subsubsection{Kepuasan Pengguna Terhadap Net Benefit}

Berdasarkan hasil pada pengujian uji t, dapat disimpulkan bahwa kepuasan pengguna memiliki pengaruh yang signifikan terhadap net benefit. Hal ini dibuktikan dengan lebih besarnya nilai signifikan yang lebih kecil dari taraf signifikan $(0,000<0,1)$ sehingga terdapat pengaruh yang signifikan dan besarnya t hitung dibandingkan dengan pada t tabel $(25,939>1,664)$, sehingga $\mathrm{H}_{a(4)}$ diterima.

$\mathrm{H}_{a(4)}$ : Terdapat pengaruh yang signifikan antara variabel kepuasan pengguna (user satisfication) dengan manfaat-manfaat bersih (net benefit).

\subsection{Uji Pengukuran Kesuksesan}

Penentuan tingkat kesuksesan sistem informasi KRS-online UMM memerlukan poin dan variabel yang sudah diperoleh dari hasil penyebaran kuesioner, hasil tanggapan dari responden dapat dilihat pada Tabel 6 .

Tabel 6. Tabel Data Tanggapan Tiap Responden

\begin{tabular}{|c|c|c|c|c|c|c|}
\hline \multirow[t]{2}{*}{ No. } & \multirow[t]{2}{*}{ Poin Pengukuran } & $\begin{array}{c}\text { Sangat } \\
\text { Tidak } \\
\text { Setuju }\end{array}$ & $\begin{array}{l}\text { Tidak } \\
\text { Setuju }\end{array}$ & Setuju & $\begin{array}{l}\text { Sangat } \\
\text { Setuju }\end{array}$ & \multirow[t]{2}{*}{ Rata-Rata } \\
\hline & & 1 & 2 & 3 & 4 & \\
\hline 1. & KS1 & 3 & 13 & 65 & 19 & 3 \\
\hline 2. & KS4 & 5 & 27 & 57 & 11 & 2,73 \\
\hline 3. & KS5 & 15 & 43 & 35 & 7 & 2,34 \\
\hline 4. & KS7 & 26 & 56 & 17 & 1 & 1,93 \\
\hline 5. & KS8 & 1 & 15 & 71 & 13 & 2,96 \\
\hline 6. & KS9 & 2 & 1 & 78 & 19 & 3,15 \\
\hline 7. & $\mathrm{KI} 11$ & 0 & 19 & 67 & 14 & 2,94 \\
\hline 8. & $\mathrm{KI} 12$ & 2 & 20 & 65 & 13 & 2,9 \\
\hline 9. & KI13 & 3 & 12 & 67 & 18 & 2,98 \\
\hline 10. & KI14 & 4 & 17 & 72 & 7 & 2,83 \\
\hline 11. & $\mathrm{~K} I 15$ & 0 & 14 & 76 & 10 & 2,97 \\
\hline 12. & $\mathrm{KI} 16$ & 1 & 17 & 70 & 12 & 2,94 \\
\hline 13. & $\mathrm{KI} 17$ & 0 & 11 & 81 & 8 & 2,98 \\
\hline 14. & KL20 & 2 & 19 & 67 & 12 & 2,9 \\
\hline 15. & KL21 & 4 & 26 & 64 & 6 & 2,73 \\
\hline 16. & KL22 & 2 & 13 & 63 & 22 & 3,06 \\
\hline 17. & KL23 & 7 & 24 & 55 & 14 & 2,76 \\
\hline 18. & KL24 & 6 & 23 & 62 & 9 & 2,74 \\
\hline 19. & KL26 & 30 & 52 & 18 & 0 & 1,86 \\
\hline 20. & KP27 & 1 & 24 & 69 & 6 & 2,8 \\
\hline 21. & KP28 & 5 & 28 & 62 & 5 & 2,68 \\
\hline 22. & NB29 & 2 & 23 & 66 & 9 & 2,81 \\
\hline 23. & NB30 & 5 & 18 & 64 & 13 & 2,85 \\
\hline 24. & NB31 & 0 & 9 & 78 & 13 & 3,04 \\
\hline 25. & NB32 & 5 & 19 & 64 & 12 & 2,84 \\
\hline 26. & NB33 & 7 & 14 & 67 & 12 & 2,83 \\
\hline 27. & NB34 & 1 & 11 & 70 & 18 & 3,04 \\
\hline 28. & NB35 & 2 & 9 & 70 & 19 & 3,05 \\
\hline 29. & NB37 & 0 & 4 & 73 & 23 & 3,18 \\
\hline
\end{tabular}

Data tanggapan 100 responden yang tampak pada Tabel 6 akan digunakan untuk menentukan persentase kesuksesan sistem informasi dan menghasilkan nilai rata-rata item. Nilai total rata-rata item adalah 81,83 dan akan digunakan untuk mengukur bobot rata-rata item yang ditunjukkan pada Persamaan 2. 


$$
\text { Bobot rata }- \text { rata item pengukuran }=\frac{81,83}{29}=2,82
$$

Langkah selanjutnya adalah mencari persentase kesuksesan. Bobot rata-rata item pengukuran dibagi dengan nilai maksimal dari skala yaitu 4 kemudian dikalikan dengan $100 \%$. Pembagian tingkat kesuksesan ini mengadopsi dari penelitian Utami, Ardini dan Purwanto, Ari (2007) yang ditunjukkan pada Persamaan 3.

$$
\text { Persentase Kesuksesan SI }=\frac{2,82}{4} x 100 \%=70,5 \%
$$

Berdasarkan hasil analisis yang dilakukan terhadap sistem informasi KRS-online UMM, nilai tingkat kesuksesannya sebesar 70,5\% dan dibandingkan dengan tabel tingkat kesuksesan [10], maka $70,5 \%$ berada pada tingkat 4 antara $61 \%$ - $80 \%$ yaitu sukses.

\section{Kesimpulan}

Berdasarkan hasil penelitian dan pembahasan, maka dapat diambil kesimpulan dan saran sebagai berikut:

1. Variabel kualitas sistem sebesar 2,742 memiliki pengaruh yang signifikan terhadap kepuasan pengguna sebesar 1,664 pada sistem informasi KRS-online Universitas Muhammadiyah Malang yang ditunjukkan oleh nilai signifikan 0,007.

2. Variabel kualitas informasi sebesar 1,760 memiliki pengaruh yang signifikan terhadap kepuasan pengguna sebesar 1,664 pada sistem informasi KRS-online Universitas Muhammadiyah Malang yang ditunjukkan oleh nilai signifikan 0,082.

3. Variabel kualitas layanan sebesar 2,264 memiliki pengaruh yang signifikan terhadap kepuasan pengguna sebesar 1,664 pada sistem informasi KRS-online Universitas Muhammadiyah Malang yang ditunjukkan oleh nilai signifikan 0,026.

4. Variabel kepuasan pengguna sebesar 5,939 memiliki pengaruh yang signifikan terhadap net benefit sebesar 1,664 pada sistem informasi KRS-online Universitas Muhammadiyah Malang yang ditunjukkan oleh nilai signifikan 0,000.

5. Berdasarkan hasil dari penelitian ini menunjukkan bahwa tingkatan kesuksesan sistem informasi KRS-online Universitas Muhammadiyah Malang yang digunakan Universitas Muhammadiyah Malang yaitu krs.umm.ac.id adalah sukses.

Saran yang dapat diberikan dari penelitian adalah sebagai berikut :

1. Penelitian ini menggunakan taraf kesalahan $10 \%$, sehingga jumlah responden hanya sedikit dan diharapkan peneliti berikutnya dapat menggunakan jumlah responden yang lebih besar.

2. Bagi developer untuk meningkatkan kualitas sistem informasi KRS-online agar berada pada tingkatan sangat sukses.

3. Peneliti selanjutnya dianjurkan meneliti sistem informasi yang melengkapi semua variabel kesuksesan DeLone and Mclean.

4. Mengidentifikasi variabel lain yang memiliki dasar teori yang kuat untuk dimasukkan dalam model analisis kesuksesan sistem informasi.

\section{Referensi}

[1] M. Salim, "Analisis Kesuksesan Sistem Informasi Perpustakaan Senayan Dengan Pendekatan Model Delone dan McLean," IGRASS, 2014. [Online]. Available: http://eprints.uny.ac.id/11158/.

[2] D. Radityo, "Pengujian Model DeLone and McLean Dalam Pengembangan Sistem Informasi Manajemen (Kajian Sebuah Kasus)," in Simposium Nasional Akuntansi X, 2007, Pp. 1-25.

[3] W. Delone, E. McLean, "The DeLone and McLean Model of Information Systems Success: a ten-year update," Journal of Management Information System, Vol. 19, No. 4, Pp. 9-30, 2003.

[4] S. A. Saputro PH, Budiyanto AD, "Analisa Kesuksesan E-Government Menggunakan Success Model's Delone And Mclean (Studi Kasus: Pemerintah kota Pekalongan)," SENTIKA, 2016.

[5] A. W. Utami FS, "Analisa Kesuksesan Sistem Informasi Akademik di Perguruan Tinggi dengan Menggunakan D\&M IS Success Model (Studi Kasus: ITS Surabaya)," Jurnal Sistem Informasi, Vol. 4, No. 5, Pp. 294-309, 2013. 
[6] K. Falgenti, S. Pahlevi, "Evaluasi Kesuksesan Sistem Informasi ERP pada Usaha Kecil Menengah Studi Kasus: Implementasi SAP B1 di PT. CP," Jurnal Manajemen Teknologi ITB, Vol. 12, No. 2, 2013.

[7] J. livari, "An empirical test of the DeLone-McLean model of information system success," Database Adv Inf Syst., Vol. 36, No. 2, Pp. 8-27, 2005.

[8] Likert R, "A technique for the measurement of attitudes," Archives of Psychology, 1932. [Online]. Available: http://psycnet.apa.org/psycinfo/1933-01885-001.

[9] I. Ghozali, Aplikasi Analisis Multivariate Dengan Program IBM dan SPSS. Aplikasi Analisis Multivariate Dengan Program IBM SPSS 19, 2011.

[10] A. Purwanto, "Rancangan Dan Implementasi Model Pemeriksaan Kinerja Badan Pemeriksa Keuangan Republik Indonesia Atas Aplikasi E-Government Di Pemerintah Daerah," Electronic Theses \& Dissertations Repository UGM, 2007. 
